\title{
PEMBELAJARAN SENI KALIGRAFI BERBASIS EKSPERIMEN KIMIA DI SEKOLAH DASAR NEGERI 8 KAWUNGLARANG RANCAH KABUPATEN CIAMIS
}

\author{
SITI SOPIAH
}

\begin{abstract}
Learning the art of calligraphy based on chemical experiments is an activity of learning the art of calligraphy in developing the potential of students to foster creativity, instill value, and develop productive abilities by using harmless materials, namely using colored plants. The purpose of this research was to determine the process and to obtain calligraphy work in learning the art of calligraphy based on chemical experiments. The type of method used in this research is field qualitative research. The data sources in this study were divided into two: first, primary data sources consisting of the principal, educators, and students of SDN 8 Kawunglarang Rancah; second, secondary data sources obtained through tracing of various references. Furthermore, the data collection instruments used were observation, interviews, and documentation, as well as the data analysis techniques used, namely through three stages including data reduction, data presentation, and drawing conclusions. The results of this study indicate that the process of learning the art of calligraphy based on chemical experiments includes the planning, implementation, and evaluation stages. The work of SDN 8 Kawunglarang students is still in the basic stages so there are several mistakes in its making.
\end{abstract}

Keywords: Calligraphy art, chemical experiment.

\section{Pendahuluan}

Al-Quran memiliki keunikan di dalam keindahan bahasanya yang mengandung unsur-unsur kebalagaan yang tinggi, sehingga tidak satupun yang dapat menandinginya. Al-Quran merupakan kitab yang dijamin keautentikannya, mengandung ajaran universal yang tidak lekang oleh waktu maupun tidak lapuk oleh pergantian zaman. Allah swt. menurunkan al-Quran untuk menjadi pedoman bagi manusia dalam menjalani kehidupan di muka bumi (Thahir, 2019).

Al-Quran diturunkan dengan berbahasa Arab, namun tidak diperuntukkan hanya untuk kalangan orang Arab saja, melainkan untuk 
semua umat manusia dari berbagai latar bangsa dan juga bahasa (Thahir, 2019). Hal ini sesuai dengan firman Allah swt. dalam Q.S. Yusuf/12:2.

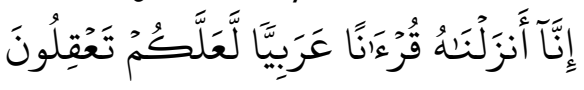

Sesungguhnya Kami menurunkannya berupa Quran berbahasa Arab, agar kamu mengerti.

Ayat ini menjelaskan bahwa Allah swt. memuji kitab-Nya yang bergitu Agung yang diturunkan kepada umat dan Rasul-Nya. Dengan menggunakan bahasa Arab yang fasih dan jelas serta dapat dipahami oleh mereka yang berakal dan berpikir (Hanif, 2018). Selain itu hikmah diturunkannya al-Quran dengan bahasa Arab agar manusia tidak mampu menyaingi kehebatan serta keindahan al-Quran, sebab kemajuan sastra pada masa itu dimiliki oleh bangsa Arab (Suaibi, 2017).

Al-Quran merupakan kitab sastra terbesar yang mengandung banyak hal terkait kandungan sastra yang luhur. Dalam penyajian ayat-ayatnya alQuran menggunakan pendekatan layaknya karya sastra (Hanif, 2018). Ia ditulis dengan tulisan yang bagus dan indah, dicetak serta disebarluaskan ke seluruh penjuru dunia. Kaum muslimin yang membacanyapun akan dinilai suatu ibadah. Karena kaum muslimin membacanya, maka al-Quran harus ditulis dengan tulisan yang baik, bagus, dan indah sehingga memberikan kesan estetis serta menarik secara visual. Agar tidak terjadi kesalahan dalam mengembangkan tradisi menulis, maka umat muslim melakukan usaha-usaha preservatif dan preventif (Suaibi, 2017).

Al-Quran diturunkan Allah swt. kepada Nabi Muhammad saw agar menuntut manusia untuk mengetahui maknanya serta mengamalkan disetiap aktivitas kehidupan sehari-hari, begitu pula dalam seni (Rispul, 2012). Seni umumnya identik dengan keindahan, tidak hanya manusia yang menyenangi keindahan melainkan Allah swt. juga menyenanginya. Hal ini tertuang dari salah satu hadits riwayat Muslim yang menyebutkan: "Sesungguhnya Allah Maha Indah, Dia suka pada keindahan". Keindahan yang disenangi Allah swt. merupakan keindahan yang sesuai dan tidak pula bertentangan dengan syariat Islam yang bersumber pada al-Quran (Hijrat, 2019).

Kaligrafi sebagai salah satu seni dari sekian banyak seni Islam yang secara khusus berkaitan dalam segi tulis menulis (Maryono, 2018). Tulis menulis yang dimaksud adalah tulisan ayat-ayat al-Qur'an yang dibuat secara indah baik dari bentuk maupun warnanya, dengan tidak menghilangkan kaidah-kaidah tulisan apalagi hingga merubah bacaan serta artinya (Zulhelman et al., 2018).

Kaligrafi al-Qur'an menyiratkan makna yang sangat mendalam, bukan hanya sekedar urutan struktur huruf-huruf (Sarif, 2016). Maksudnya kaligrafi merupakan perpaduan antara ayat yang dikutip dalam al-Qur'an dengan bentuk visual yang ditampilkan sehingga menjadi suatu karya seni yang 
dibalik keindahan visual (makna yang tersurat) juga mengandung makna non visual (makna yang tersirat) (Lukitoyo et al., 2019).

SDN 8 Kawunglarang merupakan salah satu Sekolah Dasar Negeri yang ada di kecamatan Rancah kabupaten Ciamis. Sekolah ini memasukan kaligrafi sebagai seni dalam Pendidikan Agama Islam. Selain sudah menjadi pelajaran utama seni baca dan tulis al-Quran, maka kemampuan pembuatan kaligrafinya juga mesti dimiliki para peserta didik (Suaibi, 2017). Kaligrafi sendiri tentu bukan hal yang asing bagi kalangan peserta didik, namun sepanjang pengamatan sekolah ini memperkenalkan pembelajaran seni kaligrafi berbasis eksperimen kimia.

Kimia merupakan salah satu rumpun ilmu sains. Sains sendiri merupakan ilmu yang mempelajari tentang alam yang berkaitan dengan lingkungan dan diri sendiri. Pembelajaran sains merupakan pembelajaran yang melibatkan peserta didik dan lingkungan secara langsung (Amalia, Saparahayuningsih, \& Suprapti, 2018). Melalui pembelajaran sains memungkinkan peserta didik melakukan eksplorasi terhadap berbagai benda, baik benda hidup maupun benda mati. Selain itu melalui sains dapat pula melatih peserta didik untuk menggunakan panca indranya dalam mengenal berbagai benda maupun peristiwa (Kasmini \& Purba, 2016).

Mengenalkan sains atau eksperimen kimia kepada peserta didik tidak perlu menggunakan zat yang berbahaya. Melainkan dapat dilakukan dengan kegiatan dan penggunaan bahan yang ada di lingkungan sekitar yang dekat dengan kehidupan peserta didik (Amalia et al., 2018). Misalnya indikator alami atau pewarna alami yang berasal dari tanaman atau tumbuh-tumbuhan seperti kunyit, kulit manggis, buah naga, dsb. Penggunaan bahan-bahan tersebut dilakukan karena jenis tanamannya mengandung senyawa pemberi warna (Sopiah et al., 2018). Dengan dilakukannya pembelajaran kaligrafi berbasis eksperimen ini, dapat membantu untuk mengetahui rahasia alam raya dan isinya serta mensyukuri ciptaan Allah swt. (Kasmini \& Purba, 2016).

Penelitian dilakukan pada peserta didik kelas V SDN 8 Kawunglarang Rancah ini bertujuan untuk mengetahui proses pembelajaran seni kaligrafi berbasis eksperimen kimia serta mengetahui hasil karya kaligrafi dalam pembelajaran seni kaligrafi berbasis eksperimen kimia di $\quad$ SDN 8 Kawunglarang Rancah kabupaten Ciamis.

\section{Kajian Teoretik}

Seni merupakan suatu hasil aktivitas batin atau kegiatan rohani yang direfleksikan dalam suatu bentuk karya yang pada akhirnya mampu membangkitkan rasa pada diri orang lain yang melihatnya. Karya seni menimbulkan reaksi sehingga penikmat seni tidak hanya menikmati karya seni yang dihadapinya melainkan dituntun untuk memberikan suatu reaksi (Safliana, 2008). 
Kaligrafi adalah seni menulis huruf-huruf Arab dengan indah, merangkai susunan huruf tunggal, letak, dan cara merangkainya menjadi sebuah kalimat yang berisi mengenai ayat-ayat al-Quran, hadits-hadits, dan kata-kata hikmah para ulama yang bijaksana (Rispul, 2012).

Eksperimen merupakan keterampilan yang sering dihubungkan dengan ilmu pengetahuan atau sains. Eksperimen atau percobaan disebut sebagai proses yang harus dikuasai peserta didik sebagai cara memahami konsep tentang suatu hal atau penguasaan peserta didik tentang konsep dasar eksperimen, bagaimana peserta didik dapat mengetahui proses terjadinya sesuatu dan mengapa sesuatu itu dapat terjadi, serta bagaimana peserta didik dapat membuat sesuatu yang berguna atau bermanfaat dari kegiatan yang dilakukan (Khaeriyah, Saripudin, \& Kartiyawati, 2018).

Kegiatan eksperimen dapat memberikan kesempatan pada peserta didik untuk merangsang serta mengembangkan kemampuan berpikir kritis, analisis, serta memecahkan masalah sehingga tercipta kegiatan yang lebih bermakna dan kondusif (Simatupang, 2017).

Kimia berarti belajar mengenai fakta dan konsep yang menggambarkan perubahan fisika pada level atomik, akan tetapi belajar kimia juga harus didasarkan pada bagaimana menguji fakta dari prinsip kimia dengan pembelajaran di dalam maupun di luar laboratorium (Megananda \& Sulistyowati, 2018).

Eksperimen kimia diterapkan dengan mengarahkan peserta didik melakukan berbagai rangkaian proses yang sudah disusun untuk menguji kebenaran suatu teori secara langsung melalui percobaan, sehingga peserta didik dapat menarik kesimpulan dari yang telah dipelajarinya secara langsung (Simatupang, 2017).

\section{Metode}

Jenis metode yang digunakan dalam penelitian ini adalah penelitian kualitatif lapangan yakni dengan mengamati fenomena yang terjadi di lapangan. Lokasi penelitian dilaksanakan di SDN 8 Kawunglarang yang berlokasi di Desa Kawunglarang, Kecamatan Rancah, Kabupaten Ciamis, Provinsi Jawa Barat. Penelitian ini menghasilkan deskriptif analisis berupa proses pembelajaran seni kaligrafi berbasis eksperimen kimia di SDN 8 Kawunglarang Rancah kabupaten Ciamis.

Adapun sumber data dalam penelitian ini terbagi menjadi dua: pertama, sumber data primer yang terdiri atas kepala sekolah, pendidik, serta peserta didik SDN 8 Kawunglarang Rancah; kedua, sumber data sekunder yang diperoleh melalui penelusuran dari berbagai referensi. Selanjutnya instrumen pengumpulan data yang digunakan adalah observasi, wawancara, dan dokumentasi, serta teknik analisis data yang digunakan yakni melalui tiga tahapan diantaranya reduksi data, penyajian data, dan penarikan kesimpulan. 


\section{HASIL PENELITIAN DAN PEMBAHASAN}

\section{Rancangan Pembelajaran Seni Kaligrafi berbasis Eksperimen Kimia}

Rencana pembelajaran seni kaligrafi berbasis eksperimen kimia di SDN 8 Kawunglarang tidak secara tertulis, tidak menggunakan kaidah-kaidah penulisan kaligrafi seperti naskhi, tsuluts, serta jenis-jenis lainnya, melainkan berlangsung sangat sederhana dalam bentuk kaligrafi lukis. Namun terdapat hal-hal yang perlu diperhatikan dalam pembelajaran seni kaligrafi berbasis eksperimen kimia yang berbeda dengan kaligrafi pada umumnya. Dimana pada umumya kaligrafi ditulis menggunakan alat tulis yakni pena, spidol, dan sebagainya. Sedangkan dalam seni kaligrafi berbasis eksperimen ini menggunakan berbagai tumbuhan pewarna serta bahan pembersih. Adapun cara mempersiapkan bahan-bahan serta alatnya yakni sebagai berikut:

Tabel 1 Persiapan Alat dan Bahan dalam Pembelajaran Seni Kaligrafi berbasis Eksperimen Kimia






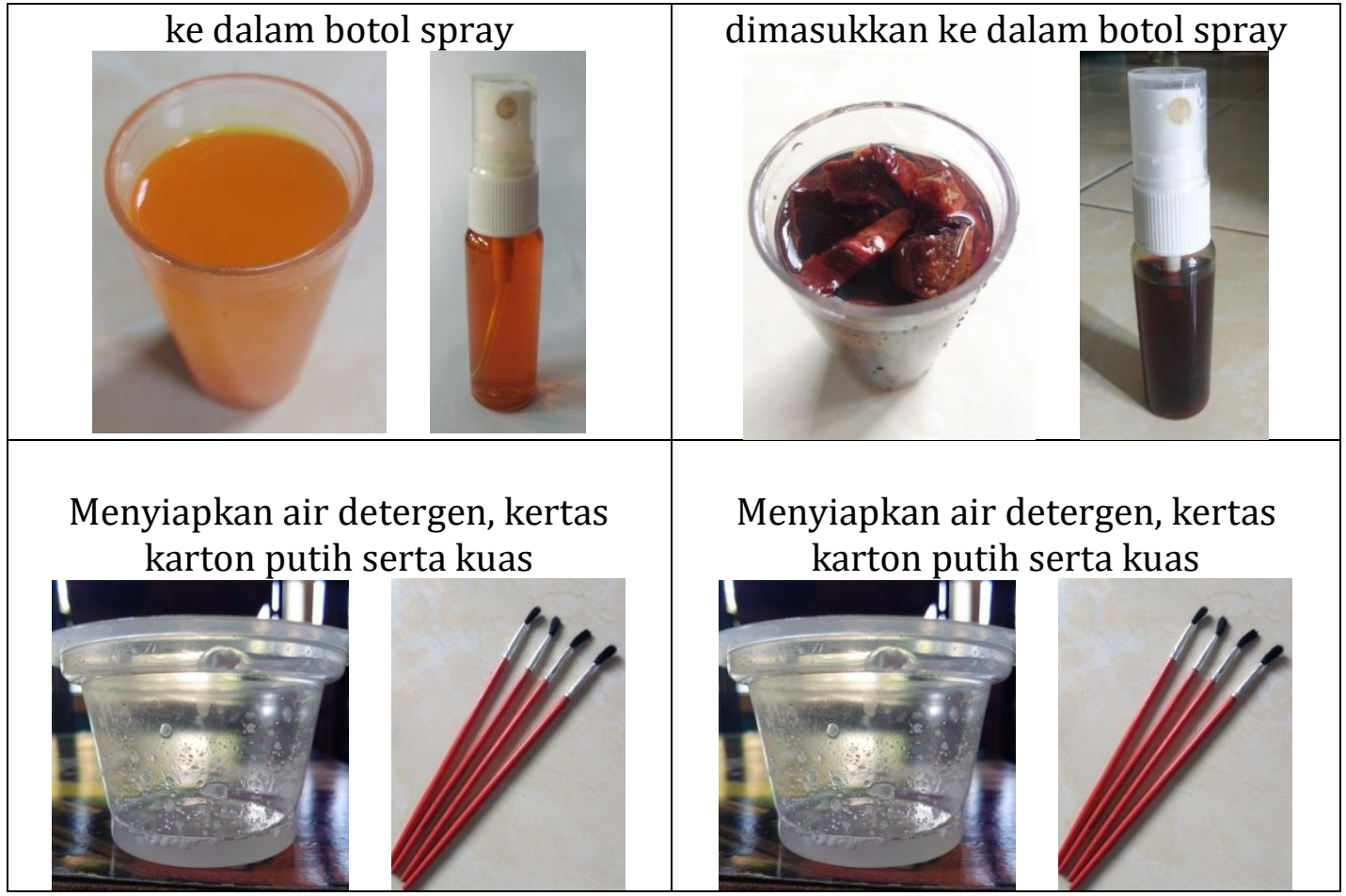

Sumber: (Dokumen Pribadi)

Pelaksanaan Pembelajaran Seni Kaligrafi berbasis Eksperimen Kimia

Adapun langkah-langkah dalam pelaksanaan pembelajaran seni kaligrafi berbasis eksperimen kimia di SDN 8 Kawunglarang sebagaimana observasi langsung peneliti ialah sebagai berikut:

a. Pendahuluan, pada awal pertemuan pendidik mengucapkan salam dan muqoddimah, lalu mengecek kehadiran peserta didik untuk menciptakan kondisi awal pembelajaran. Selanjutnya pendidik menciptakan kesiapan belajar peserta didik dengan memberikan kata-kata motivasi sebagai penyemangat peserta didik serta menciptakan suasana belajar yang kondusif. Pendidik mengajukan pertanyaan mengenai materi pembelajaran yang sudah dipelajari sebelumnya yakni menulis huruf hijaiah bersambung serta mengulas materi pembelajaran yang akan dipelajari peserta didik hari ini yakni tentang penulisan Arab atau kaligrafi dalam bentuk eksperimen.

b. Kegiatan Inti, pendidik menyampaikan materi pembelajaran dengan menggunakan metode ceramah dan metode eksperimen. Pertama, pendidik menyiapkan alat serta bahan yang akan digunakan dalam suatu eksperimen, kemudian pendidik memberikan contoh eksperimen dengan menuliskan huruf ha dhi bu menggunakan air detergen dengan bantuan kuas pada kertas karton putih. Selanjutnya kertas karton yang telah ditulisi huruf Arab tersebut didiamkan sekitar \pm 15 menit agar tulisannya menjadi kering. Setelah kering kertas karton tersebut disemprot dengan 
menggunakan campuran alkohol dengan serbuk kunyit. Semprot hingga merata sampai muncul tulisannya yang berwarna dengan sempurna. Kemudian diulangi langkah tersebut untuk menghasilkan warna yang berbeda dengan menggunakan campuran alkohol dengan potongan kulit manggis. Disini terlihat bahwa peserta didik menguasai tahapan-tahapan eksperimennya sehingga peserta didik sangat antusias dalam megikuti pembelajaran tersebut.

c. Kegiatan Akhir, pendidik mengecek hasil eksperimen peserta kemudian menyimpulkan pelajaran dengan melakukan pengulangan terhadap tahapan-tahapan dalam pembelajaran seni kaligrafi berbasis eksperimen tersebut. Kemudian pendidik memberikan pekerjaan rumah kepada para peserta didik untuk berlatih menulis Arab agar nantinya terbiasa. Dan pertemuan tersebut akhirnya ditutup dengan doa kafarah al-majlis bersama-sama.

\section{Evaluasi Pembelajaran Seni Kaligrafi berbasis Eksperimen Kimia}

Jenis evaluasi yang diharapkan adalah jenis evaluasi yang dapat memberikan kesempatan kepada para peserta didik untuk menambah kemampuan dalam pelajaran yang diajarkan pada pertemuan tersebut. Observasi langsung peneliti menunjukkan bahwa guru PAI yakni Bapak Ade Nana Rusdiana melaksanakan evaluasi berupa non tes serta berupa penugasan kepada peserta didik untuk membiasakan menulis Arab dengan baik dan benar. Baik menulis biasa dengan menggunakan pena maupun berlatih menggunakan air detergen. Kemudian dikumpulkan pada pertemuan selanjutnya.

Bapak Ade Nana Rusdiana memaparkan bahwa: "Evaluasi pada setiap pertemuan pembelajaran itu pasti ada, baik secara langsung pada saat siswa sedang belajar di Sekolah ataupun diberi pekerjaan rumah agar tetap latihan di rumah."

Evaluasi pada pembelajaran seni kaligrafi berbasis eksperimen kimia di SDN 8 Kawunglarang menurut hasil observasi peneliti dikategorikan sudah tepat, mengingat tujuan utama pembelajaran kaligrafi berbasis eksperimen ini menurut Bapak Ade Nana Rusdiana agar para peserta didik mampu dan terampil dalam menulis seni kaligrafi berbasis eksperimen kimia yang telah diajarkan. 
Hasil Karya Kaligrafi Peserta Didik dalam Pembelajaran Seni Kaligrafi berbasis Eksperimen Kimia

Tabel 2 Hasil Karya Kaligrafi Peserta Didik dalam Pembelajaran Seni Kaligrafi berbasis Eksperimen Kimia

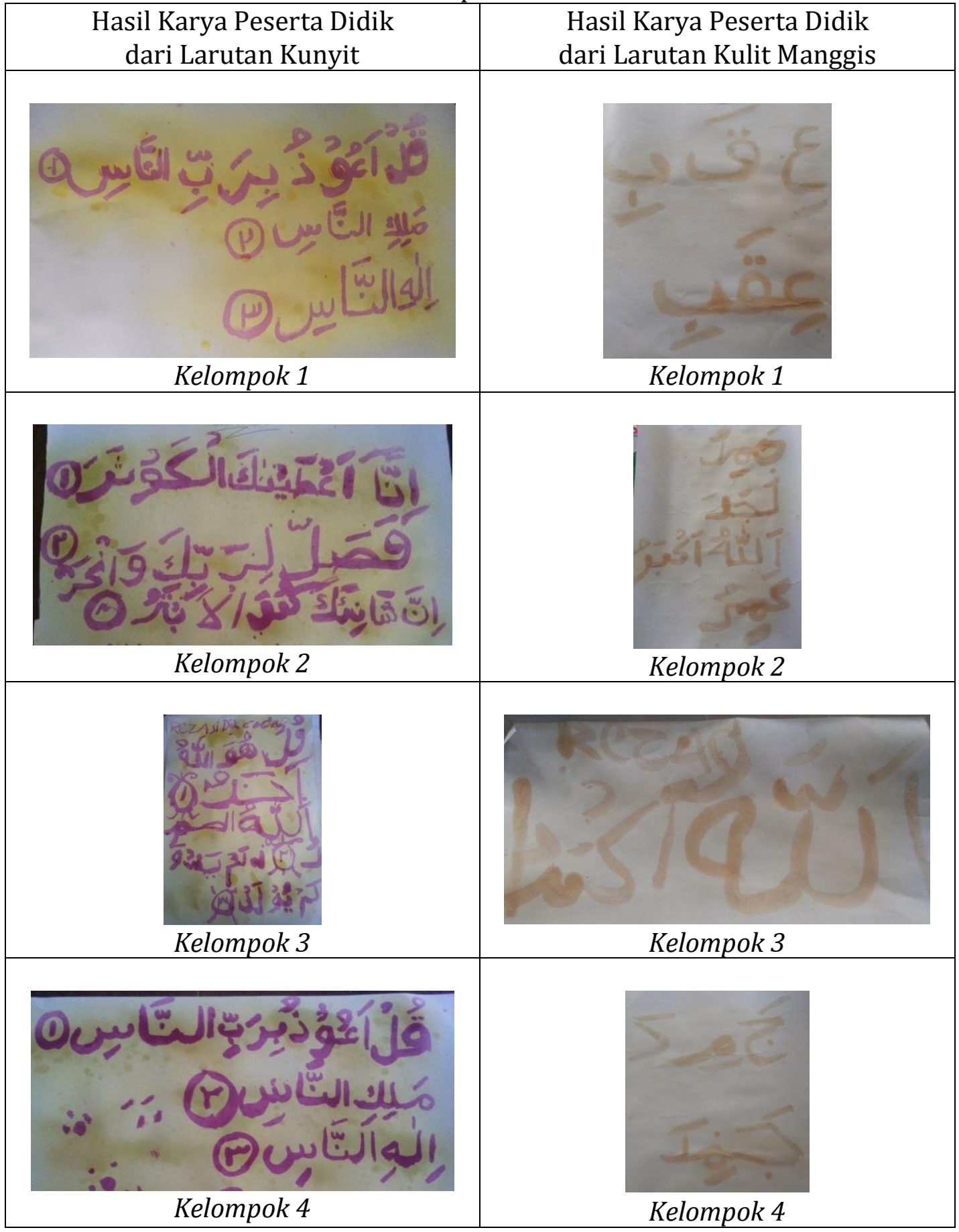

Sumber: (Dokumen Pribadi) 
Berdasarkan tabel 2 mengenai hasil karya peserta didik dalam pembelajaran seni kaligrafi berbasis eksperimen kimia dapat dipaparkan sebagai berikut:

Kelompok 1 (kunyit): Karya di atas menunjukkan tata cara penulisan yang tidak konsisten dari ayat ke ayat, ketika pada ayat pertama ditulis dengan sangat tebal sedangkan ayat berikutnya ditulis dengan sangat tipis. Begitu pula dengan ukuran hurufnya yang sebagian besar dan sebagian kecil. Serta pemilihan surah yang kurang pas dengan ukuran kertas sehingga tidak semua ayat bisa ditulis.

Kelompok 2 (kunyit): Kelebihan dari kelompok ini adalah pemilihan surah yang pas dengan ukuran kertas. Akan tetapi begitu banyak kesalahan dalam penulisannya: Pertama, spasi dari ayat ke ayat tidak sama. Kedua, penulisan yang tidak konsisten antara besar dan kecil serta tebal dan tipisnya suatu huruf. Ketiga, penulisan titik pada huruf $f a$ ayat kedua tidak tampak.

Kelompok 3 (kunyit): Karya di atas menunjukkan berbagai kesalahan, pada ayat pertama huruf qaf dalam lapadz qul tidak diberi titik. Pada ayat kedua dalam lafadz as-shomad tidak diberi tasydid pada huruf shod, tidak diberi harakat pada mim dan shod, dan pemotongan lafadz yang salah antara mim dengan dal. Pada ayat ketiga terdapat kesalahan diawal dan huruf lam pada lafadz yalid tidak terlihat serta tidak terdapat ayat terakhir. Sehingga dapat disimpulkan bahwa dilihat dari keseluruhan pun kurang indah dipandang.

Kelompok 4 (kunyit): Karya dari kelompok 4 hampir sama dengan karya kelompok 1 dimana karya tersebut menunjukkan tata cara penulisan yang tidak konsisten dari ayat ke ayat, ketika pada ayat pertama ditulis dengan sangat tebal sedangkan ayat berikutnya ditulis dengan sangat tipis. Begitu pula dengan ukuran hurufnya yang sebagian besar dan sebagian kecil. Serta pemilihan surah yang kurang pas dengan ukuran kertas sehingga tidak semua ayat bisa ditulis.

Adapun hasil karya peserta didik dalam pembelajaran seni kaligrafi berbasis eksperimen kimia dapat dipaparkan sebagai berikut:

Kelompok 1 (kulit manggis): Karya kelompok 1 di atas bagi pemula bisa dikatakan cukup karena terlihat pada penulisannya yang sedikit rapi, namun kekurangannya terlihat ada ketebalan antara qaf dan ba yang disambungkan.

Kelompok 2 (kulit manggis): Gambar di atas menunjukkan beberapa kekurangan, di antaranya pada kalimat jamidu terdapat kesalahan pada penulisan huruf jim yang menyambung, pada kalimat lajada terlihat pemberhentian penulisan antara huruf jim ke dal sehingga nampak sangat berisi, dan terakhir pada kalimat 'amiru huruf 'ain terlintas seperti huruf kaf.

Kelompok 3 (kulit manggis): Karya di atas terdapat banyak sekali kesalahan dimulai dari ketidak rapian dalam hal penulisan yakni sebagian tulisannya berukuran besar dan sebagian yang lainnya kecil, serta kesalahan pada penulisan harakatnya yang tidak sesuai misalnya huruf lam pada lafadz 
allah harus ditulis fatah berdiri, harakat dammah pada huruf hu lapadz allah seharusnya tidak menyambung pada harakat fatah huruf alif, dan terdapat kekurangan penulisan titik pada huruf $b a$, serta setelah penulisan huruf ro tidak boleh ditambah alif.

Kelompok 4 (kulit manggis): Karya kelompok terakhir ini tidak terlalu banyak kesalahan, namun meskipun demikian perlu dilatih kembali penulisan Arabnya agar terlihat rapi terutama pada ukuran penulisannya sehingga tidak besar sebelah.

Meskipun karya tersebut merupakan kaligrafi lukis yang bentuk lukisannya dibuat secara bebas tanpa terikat kaidah-kaidah baku seperti hasil kodifikasi Ibnu Muqlah. Akan tetapi kriteria untuk menilai suatu tulisan dianggap benar menurut perumusan Ibnu Muqlah dapat digunakan oleh semua jenis kaligrafi baik kaligrafi murni maupun kaligrafi lukis.

Bapak Ade Nana Rusdiana memaparkan bahwa:

"Indikator penilaian hasil karya siswa dapat mengikuti beberapa kriteria yang telah dirumuskan oleh Ibnu Muqlah seperti taufiyah (tepat), itmam (tuntas), ikmal (sempurna), isyba (padat), dan irsal (lancar)."

Bapak Ade Nana Rusdiana menambahkan: "Kriteria-kriteria penilaian tersebut bukan hanya berlaku pada jenis kaligrafi murni saja, melainkan semua jenis kaligrafi harus memiliki kriteria tersebut."

Adapun karya kaligrafi berbasis eksperimen tersebut apabila ditinjau dari kriteria penulisan menurut Bapak Ade Nana Rusdiana yakni sebagai berikut:

Tabel 3 Kriteria Penilaian Pembelajaran Seni Kaligrafi berbasis Eksperimen Kimia di SDN 8 Kawunglarang

\begin{tabular}{|c|l|l|}
\hline No. & Aspek yang Dinilai & \multicolumn{1}{|c|}{ Kriteria } \\
\hline 1. & Taufiyah & $\begin{array}{l}\text { Setiap huruf harus mendapatkan usapan yang } \\
\text { sesuai baik huruf dengan huruf maupun harakat } \\
\text { dengan harakatnya }\end{array}$ \\
\hline 2. & Itmam & $\begin{array}{l}\text { Seluruh huruf maupun harakatnya tidak ada yang } \\
\text { ketinggalan serta tidak ada pemotongan atau } \\
\text { putus dalam satu lafadz }\end{array}$ \\
\hline 3. & Ikmal & $\begin{array}{l}\text { Kalimat atau ayat tidak ditulis sebagian } \\
\text { melainkan ditulis secara utuh }\end{array}$ \\
\hline 4. & Isyba & $\begin{array}{l}\text { Terdapat keserasian atau sentuhan yang pas } \\
\text { dalam setiap usapan garis. }\end{array}$ \\
\hline 5. & Irsal & $\begin{array}{l}\text { Menuliskan kalimat tidak tertahan atau berhenti } \\
\text { di tengah-tengah sehingga menimbulkan } \\
\text { ketebalan yang berbeda yang akan merusak } \\
\text { keindahannya }\end{array}$ \\
\hline
\end{tabular}

Sumber: (Dokumen SDN 8 Kawunglarang) 
Berikut ini merupakan daftar penilaian hasil karya peserta didik dari larutan kulit manggis yang diberikan oleh guru PAI berdasarkan perspektif dari tingkat pemula:

Tabel 4 Daftar Nilai Hasil Karya Peserta Didik dari Larutan Kulit Manggis

\begin{tabular}{|c|c|c|c|c|c|c|c|c|}
\hline \multirow{2}{*}{ No. } & \multirow{2}{*}{ Kelompok } & \multicolumn{5}{|c|}{ Aspek yang Dinilai } & \multirow{2}{*}{\begin{tabular}{c}
\multirow{2}{*}{ Kata- } \\
Rata
\end{tabular}} & \\
\cline { 3 - 7 } & & Taufiyah & Itmam & Ikmal & Isyba & Irsal & Rata \\
\hline 1. & I & 70 & 65 & 65 & 70 & 70 & 68 & Cukup \\
\hline 2. & II & 65 & 65 & 63 & 65 & 65 & 65 & Cukup \\
\hline 3. & III & 60 & 60 & 63 & 60 & 60 & 61 & Cukup \\
\hline 4. & IV & 65 & 65 & 65 & 70 & 70 & 67 & Cukup \\
\hline \multicolumn{7}{|c|}{ Rata-Rata Nilai } \\
\hline
\end{tabular}

Sumber: (Dokumen SDN 8 Kawunglarang)

Adapun daftar penilaian hasil karya peserta didik dari larutan kunyit adalah sebagai berikut:

Tabel 5 Daftar Nilai Hasil Karya Peserta Didik dari Larutan Kulit Manggis

\begin{tabular}{|c|c|c|c|c|c|c|c|c|}
\hline \multirow{2}{*}{ No. } & \multirow{2}{*}{ Kelompok } & \multicolumn{5}{|c|}{ Aspek yang Dinilai } & Rata- & \multirow{2}{*}{ Ket } \\
\cline { 2 - 8 } & & Taufiyah & Itmam & Ikmal & Isyba & Irsal & Rata & \\
\hline 1. & I & 65 & 80 & 70 & 65 & 65 & 69 & Cukup \\
\hline 2. & II & 63 & 80 & 80 & 65 & 65 & 71 & Baik \\
\hline 3. & III & 60 & 60 & 70 & 65 & 65 & 64 & Cukup \\
\hline 4. & IV & 69 & 80 & 70 & 65 & 65 & 70 & Baik \\
\hline \multicolumn{8}{|c|}{ Rata-Rata Nilai } \\
\hline
\end{tabular}

Sumber: (Dokumen SDN 8 Kawunglarang)

Melihat tingkatan peserta didik dalam pembuatan seni kaligrafi berbasis eksperimen kimia masih dalam tahap pemula. Nilai-nilai di atas tergolong cukup, dalam artian karya yang ditampilkan peserta didik masih jauh dari karya kaligrafi profesional. Para peserta didik masih dalam ranah dasar dalam mempelajari seni kaligrafi.

Kesimpulan dari keseluruhan hasil karya peserta didik di atas menurut Bapak Ade Nana Rusdiana memiliki beberapa kekurangan di antaranya:

1) Peserta didik sering kali salah dalam menggunakan air detergen dengan menggunakan kuas, sehingga terjadi ceceran air detergen di atas kertas.

2) Ukuran yang tidak pas antara huruf yang tebal dan tipis.

3) Tidak memberi harakat, titik, maupun tasydid.

4) Peserta didik seringkali berhenti di tengah-tengah kalimat sehingga dapat merusak keindahan.

5) Peserta didik belum terbiasa menulis kaligrafi berbasis eksperimen.

Menulis pada dasarnya merupakan proses menggambarkan suatu bahasa sehingga dengan penggambaran tersebut si pembaca dapat memahami pesan yang disampaikan oleh si penulis. Oleh sebab itu, khususnya dalam menulis Arab dibutuhkan ketekunan, ketelitian, serta keterampilan agar bahasa yang ditampilkan dapat diterima secara baik oleh si pembaca. Kesalahan penulisan seperti pemberian harakat, pemberian titik dapat 
berakibat fatal. Karena hal tersebut menjadi hal yang paling sensitif dalam pemberian makna yang akan disampaikan, misalnya dapat mengakibatkan perbedaan pendapat. Oleh karena itu belajar menulis indah merupakan keterampilan dalam berbahasa, karena terdapat unsur penyampaian pesan yang akan disampaikan.

Demikianlah pemaparan dari hasil karya peserta didik SDN 8 Kawunglarang Rancah Kab. Ciamis. Berdasarkan hasil temuan data dari lapangan, menunjukkan bahwa hasil karya peserta didik di SDN 8 Kawunglarang dapat dikatakan sebagai pembelajaran seni kaligrafi berbasis eksperimen kimia untuk tingkat pemula. Dimana masih terdapat banyak kesalahan dalam penulisan hurufnya.

\section{Kesimpulan}

Berdasarkan hasil penelitian yang telah dilakukan peneliti yang berhubungan dengan pembelajaran seni kaligrafi berbasis eksperimen kimia di SDN 8 Kawunglarang Rancah Kab. Ciamis, maka peneliti menarik kesimpulan sebagai berikut: Proses pembelajaran seni kaligrafi berbasis eksperimen kimia di SDN 8 Kawunglarang meliputi tahap perencanaan, pelaksanaan, serta evaluasi. Perencanaan pembelajaran seni kaligrafi direncanakan tanpa tertulis, melainkan dalam proses pembelajarannya hanya mengikuti buku panduan serta kreativitas pengajar. Pelaksanaan kegiatan menggunakan metode ceramah serta metode eksperimen. Adapun evaluasi yang digunakan adalah evaluasi non tes, pendidik melakukan observasi langsung serta memberikan tugas kepada para peserta didik. Hasil karya peserta didik SDN 8 Kawunglarang masih dalam tahap pemula sehingga banyak sekali kesalahan dalam pembuatannya. Kesalahan yang sering dilakukan oleh para peserta didik di antaranya, peserta didik sering kali salah dalam menggunakan air detergen dengan menggunakan kuas, ukuran yang tidak pas antara huruf yang tebal dan tipis, tidak memberi harakat, titik, maupun tasydid, serta seringkali berhenti di tengah-tengah kalimat sehingga hal tersebut dapat merusak keindahan tulisan.

\section{DAFTAR PUSTAKA}

Amalia, K., Saparahayuningsih, S., \& Suprapti, A. (2018). Meningkatkan Kemampuan Sains Mengenal Benda Cair melalui Metode Eksperimen. Ilmiah Potensia, 3(2), 1-10.

Hanif, M. (2018). Kisah Nabi Yusuf dalam Al-Quran: Kajian Stilistika Al-Quran Surah Yusuf. Al-Af'idah, 2(2), 1-27.

Hijrat, L. akmal. (2019). Pengaruh Pendidikan Seni kaligrafi terhadap Kualitas Tulisan Arab. Pendidikan Dan Wawasan Studi Islam, 1(2), 64-71.

Kasmini, L., \& Purba, N. (2016). Pengaruh Eksperimen Sains pada Materi 
Mencampur Warna terhadap Perkembangan Kognitif Anak Kelompok B2 pada TK Pertiwi Banda Aceh. Sains, 3(1), 31-42.

Khaeriyah, E., Saripudin, A., \& Kartiyawati, R. (2018). Penerapan Metode Eksperimen dalam Pembelajaran Sains untuk Meningkatkan Kemampuan Kognitif Anak Usia Dini. Pendidikan Anak, 4(2), 102-119. Lukitoyo, P. S., Nasution, E. L., Sarini, I., \& Putra, P. I. (2019). Kaligrafi Sabut Kelapa. International Journal of Community Service Learning, 3(2), 4855.

Maryono. (2018). Nilai-Nilai Pendidikan dalam Seni Kaligrafi Karya Syaiful Adnan. Studi Keislaman, 4(1), 1-24.

Megananda, P. S. H. A., \& Sulistyowati, E. (2018). Pengembangan Buku Petunjuk Praktikum Kimia Berbasis Inkuiry Terbimbing untuk SMK Program Studi Agribisnis Produksi Tanaman kelas X Semester 2. Pembelajaran Kimia, 7(2), 46-53.

Rispul. (2012). Kaligrafi arab sebagai Karya Seni. Tsaqafa, 1(1), 9-18.

Safliana, E. (2008). Seni dalam Perspektif Islam. Islam Futura, 7(1), 100-107.

Sarif, D. (2016). Pengaruh Al-Quran terhadap Perkembangan Kaligrafi Arab. Ethnohistori, 3(2), 163-172.

Simatupang, N. I. (2017). Penerapan Metode Eksperimen terhadap Peningkatan Hasil Belajar Kimia Siswa pada Materi Laju Reaksi. Pendidikan Kimia, 9(2), 318-322.

Sopiah, S., Sari, S., \& Windayani, N. (2018). Development of Paper Indicator from Sambang Colok (Aerva sanguinolenta) Plant Extract. In IOP Conf. Series: Materials Science and Engineering (Vol. 1, pp. 1-8). https://doi.org/10.1088/1757-899X/434/1/012082

Suaibi, M. (2017). Pembelajaran Kaligrafi pada Santri Ponpes Al-Falah Lemahabang Kabupaten Luwu Utara. UIN Alauddin Makassar.

Thahir, I. (2019). Kaidah Al-Taqdim Wa Al-Takhir dalam Al-Quran. Ilmiah Islamic Resources, 16(2), 135-146.

Zulhelman, Nofrial, Prihatin, P., \& Refialisa, S. (2018). Pembuatan Kaligrafi Islam dari Bahan Limbah di MAN 3 Padangpanjang. Abdimas Mandiri, 2(2), 111-120. 
